\title{
Rancang Bangun Voice Over Internet Protocol dan GSM Gateway Berbasis Raspberry Pi
}

\section{The Design of Voice Over IP and GSM Gateway Using Raspberry Pi}

\author{
Ardi Windiarto ${ }^{1}$, Kholilatul Wardani ${ }^{{ }^{*}}$ \\ Teknik Telekomunikasi, Politeknik Kota Malang \\ Jln Tlogowaru II No. 3 Malang, Jawa Timur, Indonesia \\ ardiwindiarto@gmail.com ${ }^{1}$, kholilatulwardani@gmail.com ${ }^{2 *}$
}

\begin{abstract}
Abstrak - Makalah ini membahas desain layanan jaringan komunikasi VoIP Server menggunakan Raspberry Pi sebagai alat komunikasi wireless. VoIP server berbasis Raspberry Pi menggunakan sistem operasi RasPBX. Di dalam sistem operasi RasPBX sudah ada software asterisk yang berfungsi sebagai softswicth. Client VoIP menggunakan zoiper sebagai softphone. Alat ini dilengkapi dengan fitur GSM gateway yaitu fitur yang dapat menghubungkan jaringan VoIP ke jaringan GSM. Fitur GSM gateway ini menggunakan modem GSM sebagai jembatan yang menghubungkan jaringan VoIP dengan jaringan GSM. Persentase keberhasilan panggilan VoIP ke VoIP, VoIP ke GSM, dan GSM ke VoIP mencapai 100\%. Berdasarkan hasil pengujian Quality of services (QoS) pada panggilan VoIP ke GSM, dihasilkan rata-rata delay sebesar 12,11 ms yang termasuk dalam kategori kualitas baik, Troughput sebesar 0,151, jitter sebesar 0,052 ms yang termasuk dalam kategori kualitas baik, dan packet loss sebesar $0 \%$ yang termasuk dalam kategori kualitas sangat baik. Jangkauan maksimal antara client VoIP ke server agar komunikasi berjalan dengan baik adalah 100 meter dalam kondisi Line Of Sight (LOS). Pengujian dengan jarak 25 m dalam kondisi Non Line Of Sight (NLOS), masih menghasilkan komunikasi yang baik. Berdasarkan hasil pengujian kuisioner dari 30 pengguna, dihasilkan nilai MOS 3,88 yang termasuk dalam kategori kualitas cukup baik.
\end{abstract}

Kata Kunci: Telekomunikasi, VoIP, GSM, Raspberry Pi, Gateway.

\begin{abstract}
This paper discusses the design of VoIP Server communication network services using Raspberry $P i$ as a wireless communication device. A Raspberry Pi based VoIP server uses the RasPBX operating system. In the RasPBX operating system, there is an asterisk software that functions as Softswitch. The VoIP client uses Zoiper as a softphone. The designed tool is equipped with the GSM gateway feature which is a feature that can connect VoIP networks to GSM networks. This GSM gateway feature uses a GSM modem as a bridge that connects VoIP networks with GSM networks. The percentage of success of VoIP calls to VoIP, VoIP to GSM, and GSM to VoIP reaches 100\%. Based on the results of the Quality of Services (QoS) test on VoIP to GSM calls, an average delay of $12.11 \mathrm{~ms}$ is produced which is included in the good quality category, throughput of 0.151 , jitter of $0.052 \mathrm{~ms}$ which is included in the category of good quality, and packet loss $0 \%$ which is included in the excellent quality category. The maximum range between VoIP clients to servers so that communication runs well is 100 meters in Line Of Sight (LOS) conditions. Testing with a distance of $25 \mathrm{~m}$ in the condition of Non-Line Of Sight (NLOS) still results in good communication. Based on the results of testing questionnaires from 30 users, generated MOS of 3.88 which is included in the category of quality is quite good.
\end{abstract}

Keywords: Telecommunication, VoIP, GSM, Raspberry Pi, Gateway.

TELKA, Vol.5, No.1, Mei 2019, pp. 55 64

ISSN (e): 2540-9123

ISSN (p): 2502-1982 


\section{Pendahuluan}

Perkembangan teknologi khususnya teknologi informasi membawa perubahan yang sangat mendasar bagi dunia telekomunikasi. Dalam teknologi komunikasi, komunikasi suara merupakan satu hal yang akan menjadi bagian yang sangat penting, karena saat ini komunikasi suara dianggap komunikasi yang paling praktis. Hal ini menyebabkan hadirnya teknologi pemrosesan sinyal digital yang mempunyai kemampuan modular dengan berbasis teknologi IP (Internet Protocol) yang diintegrasikan antara komunikasi data dan suara.

Penggunaan telepon berbasis VoIP memberi banyak keuntungan terutama dari segi biaya jelas lebih murah dari biaya telepon tradisional, karena jaringan IP bersifat global. Hal ini karena VoIP dapat dipasang pada setiap Ethernet dan IP address, tidak seperti telepon tradisional yang harus mempunyai port tersendiri di Sentral atau PBX. Dalam merencanakan suatu jaringan VoIP, harus memiliki suatu server yang berfungsi sebagai IP PBX.

Beberapa penelitian mengenai pengembangan VOIP sudah banyak dilakukan dengan memanfaatkan Trixbox server [1], bahkan ada juga yang mengembangkannya dalam skema jaringan VPN [2]. Sesuai perkembangan teknologi jaringan, VOIP juga sudah ada yang mengujicobakan pada jaringan open flow [3].

Ujicoba jaringan VOIP skala terbatas seperti di gedung perkantoran dan kampus pernah dibahas pada [4] [5] [6]. Kelemahan teknologi VoIP saat ini adalah belum bisa terintegrasi dengan telepon GSM. Selain itu, diperlukan analisis terhadap Kualitas layanan $(Q o S)$ untuk memastikan bahwa layanan memenuhi syarat yang ditetapkan [7]. Berdasarkan kelemahan tersebut, maka diusulkan sebuah "Rancang Bangun Voice Over Internet Protocol Dan Gsm Gateway Berbasis Raspberry Pi“. Penggunaan Raspberry Pi pada prodi Teknik Telekomunikasi dalam kegiatan pembelajaran menggunakan mikrokomputer ini dikarenakan Raspberry Pi memiliki banyak fungsi yang banyak dibutuhkan pada jurusan Teknik Telekomunikasi. Keunggulan teknologi VoIP GSM Gateway yang menonjol adalah dapat menghubungkan jaringan VoIP ke jaringan telepon selular. VoIP GSM Gateway dapat diimplementasikan didalam suatu organisasi, institusi, dan perusahaan secara mandiri.

\section{Metode Penelitian}

Rancang Bangun Voice Over Internet Protocol dan GSM Gateway berbasis Raspberry P $i$ merupakan sebuah perangkat yang dimana didedikasikan kepada client untuk mempermudah client untuk berhubungan antara telepon VoIP dengan telepon GSM melalui wireless. Alat ini dibuat untuk memenuhi kebutuhan khususnya di perusahaan-perusahaan yang memiliki kerjasama dengan perusahaan lokal ataupun yang berada di luar negeri.

Raspberry Pi pada alat ini merupakan mikrokomputer yang memiliki pin GPIO yang dapat digunakan sebagai input dan output data Raspberry Pi. Raspberry Pi memiliki port LAN yang dapat menghubungkan Raspberry Pi dengan Ethernet. Jadi untuk satu Rancang Bangun Voice Over Internet Protocol dan GSM Gateway berbasis Raspberry P $i$, terdiri dari perangkat hardware yaitu Raspberry Pi, TP-Link Router dan modem. Sedangkan software menggunakan IP PBX dan Asterisk.

\subsection{Blok Diagram}

Sistem yang dibuat memodelkan satu kantor terpusat. Topologi yang dibangun menggunakan topologi star. Konfigurasi VoIP client dibuat untuk digunakan karyawan sebagai customer service dan untuk operasional. 


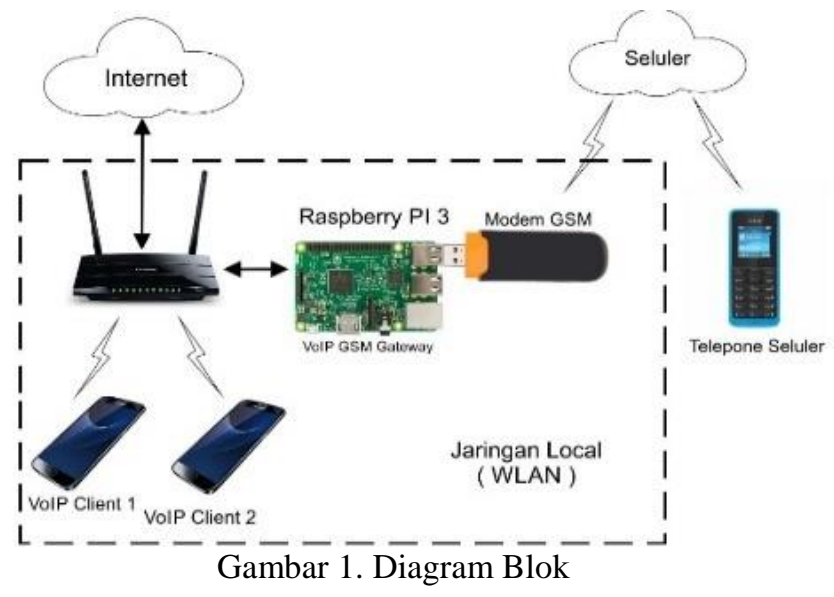

Diagram blok yang ditunjukkan pada Gambar 1 merupakan topologi jaringan dari VoIP GSM Gateway yang dikembangkan. Sistem terdiri dari Raspberry Pi yang berfungsi sebagai VoIP server dan GSM Gateway. GSM gateway terhubung dengan modem untuk terhubung ke seluler. VoIP server terhubung dengan wireless router untuk bisa diakses oleh $c l i e n t$. Client harus dilengkapi dengan aplikasi Zoiper softphone.

\subsection{Flowchart Cara Kerja Sistem}

Secara umum, tahapan kerja sistem dappat digambarkan pada Gambar 2.

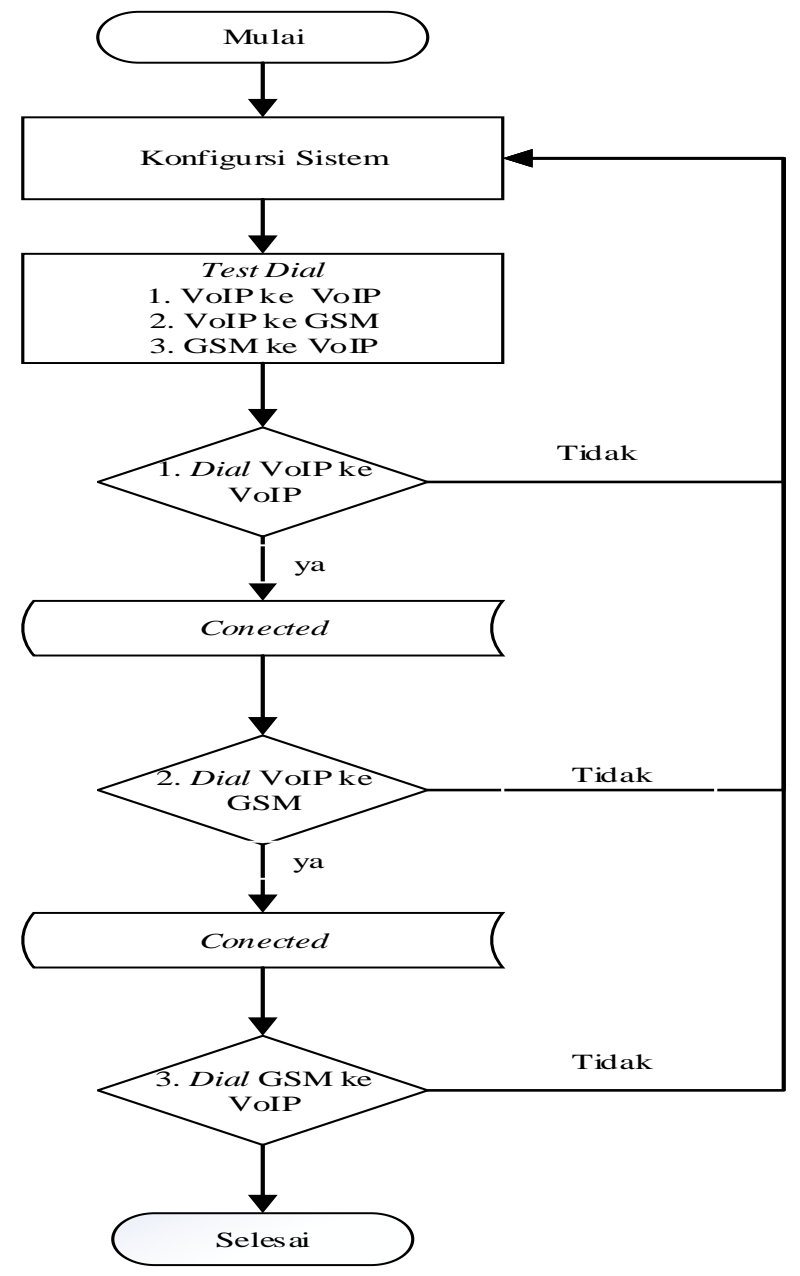

Gambar 2. Flowchart kerja sistem. 
Berdasarkan tahapan yang ditunjukkan oleh Gambar 2, langkah pertama adalah melakukan konfigurasi sistem pada sistem operasi rasPBX. Setelah konfigurasi sistem selesai, selanjutnya melakukan dial VoIP ke VoIP. Jika tidak berhasil, kembali pada tahap konfigurasi sistem. Jika berhasil selanjutnya melakukan dial VoIP ke GSM. Jika dial VoIP ke GSM tidak berhasil, kembali pada tahap konfigurasi sistem. Jika berhasil selanjutnya melakukan dial GSM ke VoIP. Jika dial VoIP ke GSM tidak berhasil, kembali pada tahap konfigurasi sistem.

\subsection{Parameter Pengujian}

Pengujian Pengujian dicatat menggunakan perangkat lunak Wireshark. Selanjutnya akan dilakukan pencatatan terhadap beberapa parameter Quality of Service $(Q o S)$.

Quality of Services adalah kemampuan dari sebuah layanan untuk menjamin performasi dan merupakan parameter untuk mengukur kualitas dari sebuah layanan. Parameter $Q o S$ yang akan dicatat dan dianalisis meliputi throughput, packet loss, delay, dan jitter [7].

\subsubsection{Delay}

Delay adalah waktu yang dibutuhkan sebuah paket untuk mencapai tujuan, karena adanya antrian yang panjang, atau mengambil rute yang lain untuk menghindari kemacetan. Waktu tunda sangat mempengaruhi kualitas layanan suara, karena pada dasarnya suara memiliki karakteristik timing. Urutan pengucapan tiap suku kata yang ditransmisikan harus sampai ke sisi penerima dengan urutan yang sama pula sehingga dapat terdengar dengan baik secara real- time. ITU (International Telecommunication Union) membagi karakteristik waktu tunda berdasarkan tingkat kenyamanan user, seperti pada Tabel 1 [7].

Tabel 1. Standar delay

\begin{tabular}{cc}
\hline Waktu Tunda $(\mathrm{ms})$ & Kualitas \\
\hline $0-150 \mathrm{~ms}$ & Baik \\
$150-300 \mathrm{~ms}$ & Cukup, masih dapat diterima \\
$>300 \mathrm{~ms}$ & Buruk \\
\hline
\end{tabular}

\subsubsection{Jitter}

Jitter merupakan perbedaan selang waktu kedatangan antar paket diterminal tujuan. Jitter dapat disebabkan oleh terjadinya kongesti, kurangnya kapasitas jaringan, variasi ukuran paket, serta ketidakurutan paket. Faktor ini perlu diperhitungkan karena karakteristik komunikasi voice adalah sensitif terhadap waktu tunda dan jitter. Untuk meminimalisasi jitter dalam jaringan maka perlu diimplementasikan suatu buffer yang akan menahan beberapa urutan paket sepanjang waktu tertentu hingga paket terakhir datang. Namun adanya buffer tersebut akan memepengaruhi waktu tunda total sistem akibat adanya tambahan proses untuk mengompensasi jitter. Tabel 2 menjelaskan mengenai standart nilai jitter yang mempengaruhi kualitas layanan VoIP [7].

Tabel 2. Standar jitter.

\begin{tabular}{cc}
\hline Waktu Tunda $(\mathrm{ms})$ & Kualitas \\
\hline $0-20 \mathrm{~ms}$ & Baik \\
$20-50 \mathrm{~ms}$ & Cukup \\
$>50 \mathrm{~ms}$ & Buruk \\
\hline
\end{tabular}

\subsubsection{Throughput}

Throughput adalah jumlah total kedatangan paket IP sukses yang diamati di tempat pengukuran pada destination selama interval waktu tertentu dibagi oleh durasi interval waktu tersebut (sama dengan, jumlah pengiriman paket IP sukses per service-second). Persamaan (1) adalah rumus dalam mencari nilai throughput

$$
\text { Throughput }=\frac{\text { Paket data yang diterima }}{\text { Lama pengamatan }}
$$




\subsubsection{Packet Loss}

Sinyal suara pada telepon internet akan ditransmisikan dalam jaringan IP dalam bentuk paket-paket IP. Karena jaringan IP merupakan best effort network maka tidak ada jaminan pada pengiriman paket tersebut. Setiap paket dapat dirutekan pada jalur yang berbeda menuju penerima. Maka dari itu tentunya akan mempengaruhi kualitas layanan. Tabel 3 memperlihatkan standar tingkat paket hilang pada jaringan [7].

Tabel 3. Packet loss.

\begin{tabular}{cc}
\hline Kategori Degredasi & Packet Loss $(\%)$ \\
\hline Baik & $0-1$ \\
Cukup & $1-2$ \\
Buruk & $>2$ \\
\hline
\end{tabular}

\subsubsection{Mean Opinion Score (MOS)}

Merupakan sistem penilaian yang berhubungan dengan kualitas suara yangdi dengar pada ujung pesawat penerima. Standar penilaian MOS dikeluarkan olehITU-T pada tahun 1996. Tabel 4 adalah tabel yang menunjukkan skala penilaian MOS. MOS memberikan penilaian kualitas suara dengan skala 1 (satu) sampai 5 (lima), dimana satu mempresentasikan nilai kualitas suara yang paling buruk danlima mempresentasikan kualitas suara yang paling baik. Penilaian denganmenggunakan MOS masih bersifat subyektif karena kualitas pendengaran danpendapat dari masing-masing pendengar berbeda-beda [7].

Tabel 4. Standar Mean Opinion Score

\begin{tabular}{cc}
\hline Kualitas Percakapan & Nilai \\
\hline Sangat Baik $($ Excellent $)$ & 5 \\
Baik (Good) & 4 \\
Cukup Baik $($ Fair $)$ & 3 \\
Kurang Baik $($ Poor $)$ & 2 \\
Buruk $($ Bad $)$ & 1 \\
\hline
\end{tabular}

\section{Hasil dan Pembahasan}

\subsection{Tes Koneksi Client ke Server}

Setelah semua client telah terhubung dengan server maka langkah selanjutnya adalah pengujiaan koneksi ke server. Pengujian ini bertujuan untuk memastikan setiap client terhubung dengan server. Pengujian pertama adalah tes ping dari client ke server VoIP. Sistem akan memberikan respon yang menunjukan apakah client terhubung atau tidak dengan server.

\subsection{Pengujian Panggilan VoIP ke VoIP}

Proses panggilan diuji pada jaringan lokal/WLAN. Setiap pengujian dilakukan sebanyak 5 kali dengan durasi 30 detik setiap pengujiannya. Pengujian dilakukan dengan cara client 1 VOIP men-dial nomor VoIP client 2 dan sebaliknya. Hasil pengujian panggilan VOIP ke VOIP ditunjukan pada Tabel 5.

Tabel 5. Panggilan VoIP ke VoIP

\begin{tabular}{ccccc}
\hline \multirow{2}{*}{ Pengujian Ke-- } & \multicolumn{2}{c}{ Test Call } & \multicolumn{2}{c}{ Keberhasilan } \\
\cline { 2 - 5 } & Outgoing & Incoming & V(Berhasil) & X(Gagal) \\
\hline 1 & 101 & 102 & $\mathrm{~V}$ & - \\
2 & 102 & 103 & $\mathrm{~V}$ & - \\
3 & 103 & 104 & $\mathrm{~V}$ & - \\
4 & 104 & 105 & $\mathrm{~V}$ & - \\
5 & 105 & 101 & $\mathrm{~V}$ & - \\
\hline
\end{tabular}




\subsection{Pengujian Panggilan VoIP ke GSM}

Tujuan dilakukan pengujian ini adalah untuk mengetahui berhasil atau tidaknya panggilan antara VoIP client dengan telepon jaringan GSM dan sebaliknya. Pengujian proses panggilan dilakukan pada jaringan lokal/WLAN. Pengujian terhadap VoIP ke GSM dilakukan sebanyak 5 kali. Pengujian dilakukan dengan cara client 1 VoIP men-dial nomor GSM dan sebaliknya. Hasil pengujian panggilan VOIP ke GSM ditampilkan pada Tabel 6.

Tabel 6. Panggilan VoIP ke GSM

\begin{tabular}{ccccc}
\hline \multirow{2}{*}{ Pengujian Ke-- } & \multicolumn{2}{c}{ Test Call } & \multicolumn{2}{c}{ Keberhasilan } \\
\cline { 2 - 5 } & Outgoing & Incoming & V(Berhasil) & X(Gagal) \\
\hline 1 & 101 & 083846296206 & V & - \\
2 & 101 & 083846296206 & V & - \\
3 & 101 & 083846296206 & V & - \\
4 & 101 & 083846296206 & V & - \\
5 & 101 & 083846296206 & V & - \\
\hline
\end{tabular}

\subsection{Pengujian Panggilan GSM ke VoIP}

Tujuan dilakukan pengujian ini adalah untuk mengetahui berhasil atau tidaknya proses panggilan antara telepon jaringan GSM dengan VoIP client dan sebaliknya. Pengujian proses panggilan dilakukan pada jaringan lokal/WLAN. Pengujian panggilan GSM ke VoIP dilakukan sebanyak 5 kali. Pengujian dilakukan dengan cara nomor GSM men-dial nomor GSM Gateway yang akan diteruskan ke nomor VoIP yang telah ditentukan. Hasil pengujian panggilan GSM ke VOIP ditunjukan pada Tabel 7.

Tabel 7. Panggilan GSM ke VoIP

\begin{tabular}{ccccc}
\hline \multirow{2}{*}{ Pengujian Ke- } & \multicolumn{2}{c}{ Test Call } & \multicolumn{2}{c}{ Keberhasilan } \\
\cline { 2 - 5 } & Outgoing & Incoming & V(Berhasil) & X(Gagal) \\
\hline 1 & 083846296206 & $083848422313(100)$ & $\mathrm{V}$ & - \\
2 & 083846296206 & $083848422313(100)$ & $\mathrm{V}$ & - \\
3 & 083846296206 & $083848422313(100)$ & $\mathrm{V}$ & - \\
4 & 083846296206 & $083848422313(100)$ & $\mathrm{V}$ & - \\
5 & 083846296206 & $083848422313(100)$ & $\mathrm{V}$ & - \\
\hline
\end{tabular}

\subsection{Pengujian QoS Panggilan VoIP ke VoIP}

Pada pengujian $Q o S$ pada panggilan VoIP ke VoIP dilakukan dengan cara pengambilan data dengan menggunakan aplikasi wireshark. pengujian dilakukan sebanyak 5 kali dan waktu komunikasi selama 30 detik setiap pengujiannya. Pengujian parameter $Q o S$ panggilan VOIP ke VOIP dituangkan pada Tabel 8.

Tabel 8. Pengujian QOS VoIP ke VoIP

\begin{tabular}{llcccccc}
\hline \multirow{2}{*}{ No } & \multirow{2}{*}{ Parameter } & \multicolumn{7}{c}{ Pengujian Ke- } & \multirow{2}{*}{ Rata-rata } \\
\cline { 3 - 7 } & & 1 & 2 & 3 & 4 & 5 & \\
\hline 1 & Delay (ms) & 11,06 & 12,55 & 10,57 & 10,40 & 11,03 & 11,12 \\
2 & Throughput(Mbps) & 0,153 & 0,134 & 0,159 & 0,163 & 0,154 & 0,153 \\
3 & Jitter(ms) & 0,04 & 0,24 & 0,02 & 0,06 & 0,05 & 0,082 \\
4 & Packet Loss(\%) & 0 & 0 & 0 & 0 & 0 & 0 \\
\hline
\end{tabular}

Pengujian $Q o S$ komunikasi VoIP ke VoIP pada Tabel 8 menghasilkan rata-rata delay sebesar 11, 12 ms termasuk dalam kategori kualitas baik. Jitter sebesar 0,082 ms termasuk dalam kategori kualitas baik. Packet loss sebesar 0\% termasuk dalam kategori kualitas baik, dan berdasarkan perhitungan diapat troughput sebesar 0,153 Mbps. 


\subsection{Pengujian QoS Panggilan VoIP ke GSM}

Pada pengujian $Q o S$ pada panggilan VoIP ke GSM dilakukan dengan cara pengambilan data dengan menggunakan aplikasi wireshark. pengujian dilakukan sebanyak 5 kali dan waktu komunikasi selama 30 detik setiap pengujiannya. Hasil pengujian $Q o S$ komunikasi VoIP ke GSM dituangkan pada Tabel 9.

Tabel 9. Pengujian $Q O S$ VoIP ke GSM

\begin{tabular}{llcccccc}
\hline \multirow{2}{*}{ No } & \multirow{2}{*}{ Parameter } & \multicolumn{7}{c}{ Pengujian Ke- } & \multirow{2}{*}{ Rata-rata } \\
\cline { 3 - 7 } & & 1 & 2 & 3 & 4 & 5 & \\
\hline 1 & Delay (ms) & 9,68 & 14,93 & 14,33 & 11,16 & 10,47 & 12,11 \\
2 & Throughput(Mbps) & 0,177 & 0,121 & 0,155 & 0,165 & 0,135 & 0,151 \\
3 & Jitter(ms) & 1,24 & 0,32 & 0,94 & 0,03 & 0,08 & 0,52 \\
4 & Packet Loss(\%) & 0 & 0 & 0 & 0 & 0 & 0 \\
\hline
\end{tabular}

Pengujian $Q o S$ komunikasi VoIP ke GSM menghasilkan rata-rata delay sebesar 12,11 ms yang termasuk dalam kategori kualitas baik. Jitter sebesar 0,052 ms termasuk dalam kategori kualitas baik. Packet loss sebesar 0\% termasuk dalam kategori kualitas baik. Dan berdasarkan perhitungan, diperoleh troughput sebesar 0,151 Mbps.

\subsection{Pengujian QoS Panggilan GSM ke VOIP}

Pada pengujian $Q o S$ pada panggilan GSM ke VoIP dilakukan dengan cara pengambilan data dengan menggunakan aplikasi wireshark. Pengujian dilakukan sebanyak 5 kali dengan durasi komunikasi selama 30 detik setiap pengujiannya. Hasil pengujian $Q o S$ panggilan dari GSM ke VOIP dituangkan dalam Tabel 10.

Tabel 10. Pengujian QoS GSM ke VoIP

\begin{tabular}{llcccccc}
\hline \multirow{2}{*}{ No } & \multirow{2}{*}{ Parameter } & \multicolumn{7}{c}{ Pengujian Ke- } & \multirow{2}{*}{ Rata-rata } \\
\cline { 3 - 7 } & & 1 & 2 & 3 & 4 & 5 & \\
\hline 1 & Delay $(\mathrm{ms})$ & 13,29 & 12,55 & 13,03 & 12,93 & 12,55 & 12,87 \\
2 & Throughput(Mbps) & 0,129 & 0,137 & 0,132 & 0,134 & 0,137 & 0,134 \\
3 & Jitter(ms) & 2,22 & 0,03 & 0,02 & 0,03 & 0,03 & 0,834 \\
4 & Packet Loss $(\%)$ & 0 & 0 & 0 & 0 & 0 & 0 \\
\hline
\end{tabular}

\subsection{Pengujian Area Jaringan Local (WLAN)}

Tujuan dilakukan pengujian area jaringan local (WAN) ini yaitu untuk mengetahui jarak yang dapat dijangkau oleh VoIP client 1 dengan VoIP client 2 menggunakan wireless router TPLINK TL-WR841ND dengan wireless transmit power (MAX) $20 \mathrm{dBm}$. Pengujian ini dilakukan dengan cara VoIP client 1 memanggil nomor client 2 dengan jarak yang telah ditentukan. Pengujian ini dilakukan dengan dua kondisi yaitu kondisi LOS atau kondisi tanpa halangan dan NLOS atau kondisi banyak halangan seperti gedung. Skema pengujian jangkauan VOIP pada WLAN ditunjukkan pada Gambar 3.

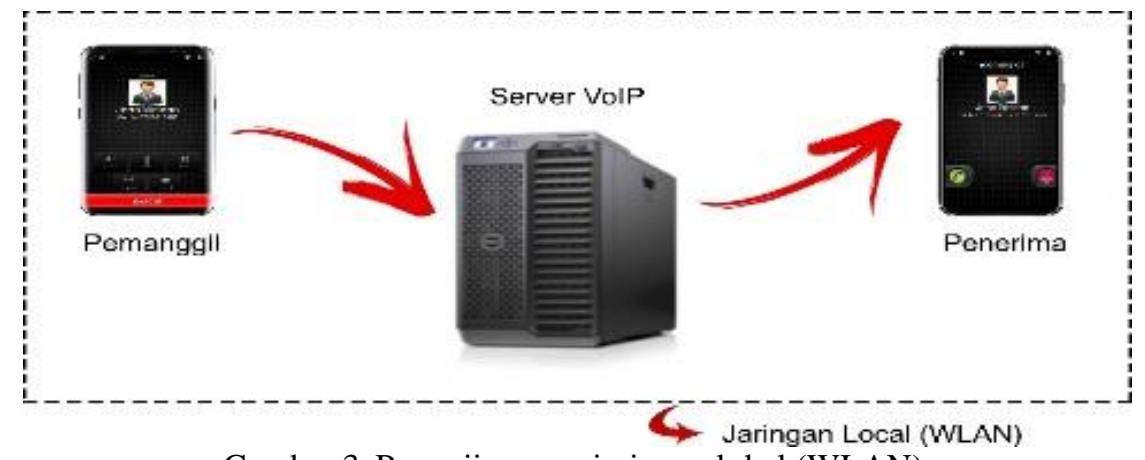

Gambar 3. Pengujian area jaringan lokal (WLAN). 


\subsubsection{Pengujian Jangkauan pada Kondisi Line of Sight (LOS)}

Hasil pengujian jangkauan dengan kondisi LOS dituangkan pada Tabel 11.

Tabel 11. Pengujian area pada kondisi LOS

\begin{tabular}{ccccc}
\hline \multirow{2}{*}{ Pengujian Ke- } & \multirow{2}{*}{ Jarak $(\mathrm{m})$} & \multicolumn{2}{c}{ Keberhasilan } & \multirow{2}{*}{ Keterangan } \\
\cline { 3 - 4 } & & $\mathrm{V}($ Berhasil $)$ & $\mathrm{X}(\mathrm{Gagal})$ & \\
\hline 1 & 25 & $\mathrm{~V}$ & - & Stabil \\
2 & 50 & $\mathrm{~V}$ & - & Stabil \\
3 & 75 & $\mathrm{~V}$ & - & Stabil \\
4 & 100 & $\mathrm{~V}$ & - & Stabil \\
5 & 125 & $\mathrm{~V}$ & - & Stabil \\
6 & 150 & $\mathrm{~V}$ & - & Tidak Stabil \\
\hline
\end{tabular}

Metode pengujian LOS dilakukan dengan cara client 1 dan client 2 saling melakukan komunikasi dalam keadaan tanpa ada halangan. pada Tabel 4.8 ditunjukkan bahwa dengan 5 kali pengujian dapat disimpulkan jarak jangkauan area client VoIP ke server untuk melakukan komunikasi dengan baik dibutuhkan jarak 100 meter dalam kondisi Line Of Sight (LOS). Dalam jarak 150 masih bisa melakukan komunikasi tetapi tidak stabil.

\subsubsection{Pengujian Jangkauan pada Kondisi Non Line of Sight (NLOS)}

Hasil pengujian jangkauan dengan kondisi LOS dituangkan pada Tabel 12.

Tabel 12. Pengujian Non Area Line Of Sight(NLOS)

\begin{tabular}{ccccc}
\hline \multirow{2}{*}{ Pengujian Ke- } & \multirow{2}{*}{ Jarak $(\mathrm{m})$} & \multicolumn{2}{c}{ Keberhasilan } & \multirow{2}{*}{ Keterangan } \\
\cline { 3 - 4 } & & $\mathrm{V}($ Berhasil $)$ & $\mathrm{X}($ Gagal $)$ & \\
\hline 1 & 10 & $\mathrm{~V}$ & - & Stabil \\
2 & 20 & $\mathrm{~V}$ & - & Stabil \\
3 & 30 & - & $\mathrm{X}$ & Tidak Terkoneksi \\
4 & 40 & - & $\mathrm{X}$ & Tidak Terkoneksi \\
5 & 50 & - & $\mathrm{X}$ & Tidak Terkoneksi \\
\hline
\end{tabular}

Metode pengujian NLOS dilakukan dengan cara client 1 dan client 2 melakukan komunikasi dengan halangan di gedung A lantai 2 Politeknik Kota Malang sebagaimana ditunjukan pada Gambar 4. Berdasarkan Tabel 12, dengan 5 kali pengujian dapat disimpulkan bahwa pada jangkauan client VoIP ke server sejauh 25 meter dan dalam kondisi NLOS, masih bisa dilakukan komunikasi. Pada kondisi NLOS, terjadi loss koneksi pada jarak 30 meter. 


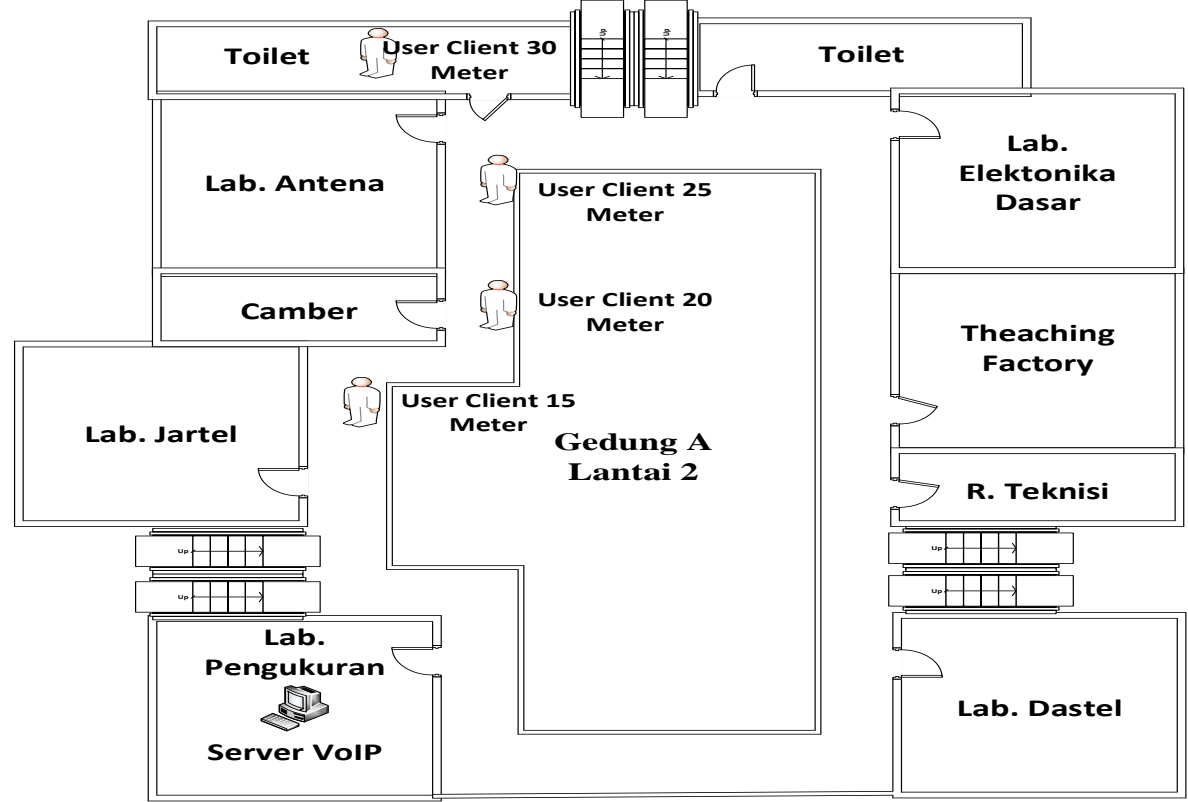

Gambar 4. Denah pengujian NLOS

\subsubsection{Mean Opinion Score (MOS)}

Untuk mengetahui penilaian pengguna terhadap kualitas VOIP yang dibangun, dilakukan survey terhadap 30 orang pengguna, yang hasil kesimpulannya dapat dilihat pada Tabel 13.

Tabel 13. Kesimpulan hasil kuisioner.

\begin{tabular}{|c|c|c|c|c|c|c|c|c|c|}
\hline \multirow{4}{*}{ No } & \multicolumn{5}{|c|}{ Kategori Nilai Responden } & \multirow{4}{*}{$\begin{array}{c}\text { Total } \\
\text { Respo } \\
\text { nden }\end{array}$} & \multirow{4}{*}{$\begin{array}{c}\text { Totak } \\
\text { keselur } \\
\text { uhan }\end{array}$} & \multirow{4}{*}{$\begin{array}{l}\text { Nilai } \\
\text { MOS }\end{array}$} & \multirow{4}{*}{ Kategori } \\
\hline & 1 & 2 & 3 & 4 & 5 & & & & \\
\hline & $\Sigma \mathrm{Xi} . \mathrm{K}$ & $\Sigma \mathrm{Xi} . \mathrm{K}$ & $\sum \mathrm{Xi} . \mathrm{K}$ & $\sum \mathrm{Xi} . \mathrm{K}$ & $\sum \mathrm{Xi} . \mathrm{K}$ & & & & \\
\hline & $\sum \mathrm{Xi} .1$ & $\sum \mathrm{Xi} .2$ & $\sum X i .3$ & $\sum \mathrm{Xi} .4$ & $\sum X i .5$ & & & & \\
\hline 1 & 3 & 0 & 0 & 0 & 27 & 30 & 138 & 4,6 & Baik \\
\hline 2 & 0 & 2 & 8 & 16 & 4 & 30 & 112 & 3,73 & Cukup Baik \\
\hline 3 & 0 & 0 & 8 & 15 & 7 & 30 & 119 & 3,96 & Cukup Baik \\
\hline 4 & 3 & 5 & 14 & 7 & 1 & 30 & 88 & 2,93 & Cukup \\
\hline 5 & 0 & 3 & 19 & 6 & 2 & 30 & 97 & 3,23 & Cukup Baik \\
\hline 6 & 0 & 0 & 0 & 0 & 30 & 30 & 150 & 5 & Sangat Baik \\
\hline 7 & 11 & 0 & 0 & 0 & 19 & 30 & 106 & 3,5 & Cukup Baik \\
\hline 8 & 0 & 0 & 6 & 8 & 16 & 30 & 130 & 4,33 & Baik \\
\hline 9 & 12 & 0 & 0 & 0 & 18 & 30 & 78 & 2,6 & Cukup \\
\hline 10 & 0 & 1 & 4 & 21 & 3 & 30 & 113 & 3,76 & Cukup Baik \\
\hline 11 & 0 & 0 & 0 & 0 & 30 & 30 & 150 & 5 & Sangat Baik \\
\hline 12 & 0 & 0 & 7 & 17 & 6 & 30 & 119 & 3,96 & Cukup Baik \\
\hline 13 & 0 & 0 & 10 & 15 & 5 & 30 & 115 & 3,83 & Cukup Baik \\
\hline & & & & mpulan & & & & 3,83 & Cukup Baik \\
\hline
\end{tabular}

Nilai rata- rata MOS diperoleh dari total nilai keseluruhan pada masing-masing pertanyaan dibagi total responden. Kesimpulan diperoleh dengan cara nilai rata-rata MOS masing-masing pertanyaan dijumlahkan dan dibagi dengan jumlah pertanyaan.

\section{Kesimpulan}

Dari hasil implementasi dan pengujian sistem yang telah dilakukan, dapat disimpulkan bahwa sistem yang dibangun sudah berhasil dengan presentase keberhasilan panggilan VoIP ke VoIP yaitu sebesar 100\%., presentase keberhasilan panggilan VoIP ke GSM yaitu sebesar 100\%, 
dan presentase keberhasilan panggilan GSM ke VoIP sebesar 100\%.. Dari sisi QOS, sistem sudah menunjukan kualitas yang baik, memenuhi standar komunikasi yang ditetapkan ITU-T, baik dari sisi jitter, packet loss, delay dan throughput. Jangkauan maksimum client VoIP ke server agar dapat melakukan panggilan VoIP ke VoIP dengan baik adalah sejauh 100 meter dalam kondisi Line Of Sight (LOS). Pada jarak 150 meter masih bisa melakukan komunikasi tetapi tidak stabil. Sementara itu, jangkauan client VoIP ke server sejauh 25 meter dan dalam kondisi NLOS, masih bisa dilakukan komunikasi/panggilan VOIP. Pada kondisi NLOS, terjadi loss koneksi pada jarak 30 meter. Berdasarkan data-data pengujian yang diperoleh, sistem VOIP dan GSM gateway ini bisa digunakan sebagai media komunikasi untuk memanggil nomor GSM semua operator yang terletak di luar jangkauan sistem.

\section{Referensi}

[1] E. S. Permadi, "Rancang Bangun Jaringan Komunikasi VoIP Server Portable Menggunakan Raspberry Pi.," Tek. Telekomun. Politek, Kota Malang, 2015.

[2] H. Khuluq, "Implementasi VOIP (Voice Over Internet Protocol) Server Berbasis Raspberry pi Sebagai Media Komunikasi," Edutic-Scientific Journal of Informatics Education, vol. 3, no. 1, pp. 44-47, 2016.

[3] E. A. Z. Hamidi, M. R. Effendi dan H. W. Widodo, "Prototipe Layanan VoIP Pada Jaringan OpenFlow," TELKA, vol. 4, no. 1, pp. 33-42, 2018.

[4] A. Pradipta, A. W. W. Nugraha dan I. Setiawan, "Unjuk Kerja Voice Over Internet Protocol pada Jaringan Lokal Universitas Jenderal Soedirman,” Dinamika Rekayasa, vol. 8, no. 2, pp. 56-62, 2012.

[5] A. Setiawan, "Analisis Simulasi Mobile VoIP (Voice Over Internet Protocol) Berbasis SIP (Session Initiation Protocol) Pada Jaringan Wireless di Gedung FTI UKSW," Program Studi Teknik Informatika FTI-UKSW, Salatiga, 2013.

[6] H. Cahyono, "Implementasi Server VoIP IP PBX untuk Meningkatkan Kualitas Layanan PABX," Universitas Kanjuruhan Malang, Malang, 2012.

[7] B. Yonathan, Y. Bandung dan A. Z. Langi, "Analisis Kualitas Layanan $(Q o S)$ audio-video layanan kelas virtual di jaringan digital learning pedesaan," dalam Proceeding of Konferensi Teknologi Informasi dan Komunikasi untuk Indonesia, Bandung, 2011. 